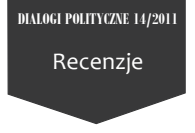

JAKUB CHMIELNIAK

Uniwersytet Mikołaja Kopernika

\title{
Prawda filozofii a prawda historii: o tyranii Leo Straussa
}

Drzygotowanie recenzji dzieła tak ważnego, jak O tyranii, stanowi przedsięwzięcie nadzwyczaj trudne i ryzykowne. Oto bowiem czytelnik staje przed zadaniem prezentacji wypowiedzi, których autorzy, Leo Strauss i Alexandre Kojève, należą niewątpliwie do grona najwybitniejszych umysłowości swoich czasów. Rzetelny recenzent, chcąc oddać sprawiedliwość tej lekturze, musiałby wznieść się na poziom umysłowości dalece przekraczający przeciętność; w przeciwnym razie przekłamie i zniekształci wyczytane treści, tym samym - nie powiedzie mu się próba zrozumienia autorów tak, jak oni rozumieli samych siebie. Można sądzić, iż namysł nad zasadniczymi pytaniami zawartymi w tej książce, próba nakierowania czytelnika na fundamentalne zagadnienia, które podejmują obaj myśliciele - co zapewne pozwoli wreszcie ujrzeć samo sedno argumentacji i niezgody między nimi - okazuje się w takim razie jedyną właściwą ścieżką, jaką powinien podążyć recenzent.

Sama obfitość i różnorodność tekstów pomieszczonych w polskim wydaniu $O$ tyranii, opartym na wydaniu amerykańskim z roku 2000, może zawrócić w głowie. Czytelnik otrzymuje pozycję zawierającą nieco zapomniany dialog Ksenofonta pt. Hieron, komentarz Leo Straussa, recenzję Alexandre'a Kojève'a zatytułowaną Tyrania i mądrość, odpowiedź amerykańskiego myśliciela o tytule Hieron Ksenofonta: Rekapitulacja, a także zbiór korespondencji. Całość, w amerykańskim dyskursie naukowym, określana jest jako (publiczna i prywatna) „debata Strauss - Kojève”. Dodatkowo, polskie wydanie zawiera Wrowadzenie napisane przez Victora Goure- 
vitcha i Michaela S. Rotha, redaktorów wydania amerykańskiego. Tłumaczami są dwaj młodzi badacze z Krakowa, Paweł Armada i Arkadiusz Górnisiewicz, z których przynajmniej jeden wykazuje się w ramach swego dorobku naukowego istotną znajomością spuścizny intelektualnej Leo Straussa oraz złożonego zjawiska „straussizmu”. Do kwestii związanych z jakością tłumaczenia powrócę na końcu recenzji.

Niełatwe jest już bliższe określenie tematyki podejmowanej przez obu autorów. Tytuł sugerowałby politologiczną czy też filozoficzno-polityczną rozprawę z rodzaju tych, których sporo - niekiedy znakomitych pojawiło się po II wojnie światowej, a ich autorzy (np. Hannah Arendt czy Eric Voegelin ${ }^{1}$ ) podjęli wysiłek analizy nowoczesnej formy tyranii, czyli totalitaryzmu. Charakter 0 tyranii jest jednak inny: stanowi u podstaw komentarz do (niewielkich rozmiarów) dzieła klasycznego. Jej przedmiotem nie są polityczne konflikty na linii władza - lud, na co wskazać może choćby tytuł recenzji Kojève'a. Problemy podejmowane w tej książce obracają się wokół trzech pojęć: nowoczesności - człowieczeństwa - filozofii. Tyrania jako taka utożsamiona zostaje z kluczowym zagrożeniem wynikającym z istoty nowoczesności. Te wątki, jakże ważkie, pojawiają się jednak dopiero w bezpośredniej wymianie, czyli w tekstach Tyrania i mądrość oraz Hieron Ksenofonta: Rekapitulacja. Sam komentarz Straussa stanowi wspaniały punkt wyjścia do publicznej dyskusji, wprowadzając odpowiedni kształt i język. To właśnie owa dyskusja będzie nas interesować najbardziej i, być może, zaprowadzi nas do samego sedna argumentu.

Zdaniem Kojève'a, kluczowe dla zrozumienia różnicy między nami a Grekami są ostatnie zdania dialogu Ksenofonta, kiedy to poeta Symonides opisuje idealną tyranię. Ów opis, utopijny przed dwoma tysiącami lat, nam wydaje się „banalną rzeczywistością"2 - rzeczywistością państwa nowoczesnego. Wyjaśnienie tej niezwykłej konstatacji daje nam Hegel. Dialektyka Pana i Niewolnika we wspaniały sposób pokazana w dialogu po jednej stronie sytuuje się zabiegający o chwałę, honor i uznanie Pan, którego odzwierciedla tyran, po drugiej zaś: pozostający w obrębie Judeochrześcijańskiej, burżuazyjnej, tchórzliwej moralności Niewolnik, czyli poddany tyrana - przebiegająca pod znakiem ciągłego współzawodnictwa, kończy się powstaniem uniwersalnego i homogenicznego państwa. Tyran

Zob. H. Arendt, Korzenie totalitaryzmu, przeł. M. Szawiel i D. Grinberg, Niezależna Oficyna Wydawnicza, Warszawa 1993; E. Voegelin, Nowa nauka polityki, przeł. P. Śpiewak, Aletheia, Warszawa 1992.

L. Strauss, O tyranii, przeł. P. Armada, A. Górnisiewicz, Wydawnictwo Uniwersytetu Jagiellońskiego, Kraków 2009, s. 130. 
dopiero w nowoczesności może zaspokoić swą najbardziej fundamentalną potrzebę: całkowitego uznania ze strony wszystkich ludzi. Wydawać by się mogło - a sugeruje to klasyczne rozumowanie - że filozof wyłamuje się $z$ tego schematu. Kojève opisuje go jako tego, który poszukuje niezmiennego Bytu, który przez swój własny wysiłek jak i „działanie wychodzące od samej Prawdy" może uczestniczyć w tejże Prawdzie. Jako par excellence poszukującemu mądrości człowiekowi zbywa mu jednak na wolnym czasie. Właśnie w tym momencie pojawia się przed nim wybór: życie polityczne a życie kontemplacyjne. Tragizm tej sytuacji jest tragizmem ludzkiej ograniczoności bycia w czasie. Filozofia jest więc obraną przez arbitralny akt woli drogą życia. Uzupełnia tę wizję perspektywa Heglowska, sytuująca się wbrew klasycznemu rozumieniu filozofii jako drogi życia.

Hegel twierdzi - a za nim też i Kojève - że „teistyczna” koncepcja filozofii jest błędna. Bóg nie istnieje, a Byt tożsamy jest z Historią, która dopóty się staje, dopóki się nie skończy i nie zamknie w swej Prawdzie. Wieczność jest tu niczym więcej jak tylko wypełnieniem czasu. Tedy filozof, będący siłą rzeczy bliżej Prawdy, która ma dopiero nadejść, musi uczestniczyć w biegu dziejów, by aktywnie przyczyniać się do jej urzeczywistnienia. Staje się, jak ujął to Piotr Nowak w swej monografii ${ }^{4}$, filozofem praktyki - filozofem sukcesu. Idąc dalej, Kojève wskazuje, że także motywacja filozoficzna nie jest tak czysta, jak chcieliby Grecy. Poszukiwacz mądrości również pragnie uznania ze strony innych ludzi. Tym, co różni go od Tyrana, jest rodzaj uznania - nieliczni mędrcy wyżej są przezeń cenieni od ludu. Symonides „chce być podziwiany ze względu na swą doskonałość, a nie dlatego, że jest, kimkolwiek by był" ${ }^{5}$. Chwilę później jednak dowiadujemy się, że nie ma żadnej zasadniczej różnicy między oboma typami uznania przez innych, a filozof w takiej samej mierze pożąda uznania tłumu co mędrców. Wszak wychodzi na Rynek, jak Sokrates, i naucza. Pragnie, by jego idee ,urzeczywistniły się przez działanie" ${ }^{\text {.6 }}$.Jako taki - konkluduje Kojève - filozof nie różni się niczym od tyrana. Działania jednego i drugiego obliczone są na osiągnięcie sukcesu. Dramatyczny problem braku czasu u filozofa znajduje swe rozwiązanie w sojuszu, który zawiązuje on z tyranem. Przykłady daje historia: pierwsze państwo uniwersalne powstało pod rządami Aleksandra Wielkiego. To wydarzenie bez precedensu. Uczeń Arystotelesa wymyślił ideę imperium, czyli państwa,

Tamże, s. 143.

Zob. P. Nowak, Ontologia sukcesu, Słowo/obraz terytoria, Gdańsk 2006.

Tamże, s. 147.

Tamże. 
któremu a priori nikt nie wyznacza granic. Jednakże nie będąc homogenicznym, z góry skazane było ono na upadek. Dopiero chrześcijaństwo, zdaniem Kojève’a, dało podwaliny do zaistnienia państwa spełniającego oba kryteria - w momencie, gdy idea Boga, względem którego wszyscy są równi, została zsekularyzowana - zapewne przez samych chrześcijan. Tak oto koniec historii, czyli moment, w którym powstaje ostatnie państwo, jest też momentem, w którym tyran doznaje spełnienia, a filozof, dzięki historycznej weryfikacji, poznaje Prawdę i staje się mędrcem: już jej nie szuka - już ją ma.

Strauss, chcąc odeprzeć racjonalne i druzgoczące argumenty Kojève'a, musiałby udowodnić, że filozof jest kimś innym, niż tyran, że filozofii nie można zamykać w czasie, tylko że potrzebuje ona niejako zewnętrznego ładu, który jest jej pożywieniem i powietrzem, warunkiem sine qua non jej istnienia. Podstawowe pytanie, które winno być postawione, brzmi: w jaki sposób uprawomocnić filozofię tak, by ta nie została sprowadzona do Kojève'owskiej jej interpretacji. Odpowiedź, którą daje Strauss w ostatnim akapicie swojego tekstu ${ }^{7}$, poprzedza dłuższy wywód.

Nowoczesna tyrania, w odróżnieniu od jej starożytnego wzorca jest, po pierwsze, totalna (obejmuje jednako wszystkich ludzi - obywateli), po drugie - polega na totalnym zawojowaniu natury, „które umożliwiła nowoczesna nauka"8. Skoro zaszła różnica w rozumieniu świata i człowieka, należy przypuszczać, że rozumienie filozofii - takie, jakie pokutuje dziś - nie jest uprawnione, ba, nie jest prawdziwe. Błędem jest narzucanie własnych wzorów i narracji (postęp, światopogląd itd.) czasom odległym o setki lat; zabiera nam to możliwość właściwego zrozumienia autorów wówczas żyjących. Polemika z Kojèvem sprowadza się do kilku kluczowych punktów. Po pierwsze, to co w człowieku ludzkie nie pojawia się w toku postępu, lecz domaga się realizacji, dając w zamian szczęście i doskonałość. Wiąże się to z punktem drugim - antropologia Hobbesowska, którą przyjmują Hegel i Kojève, jest nieprawdziwa: założenie, że człowiekiem kieruje tylko i wyłącznie pragnienie uznania jest błędne. Wyjście filozofa do ludu tłumaczyć należy inaczej. Czyniąc rozróżnienie na „subiektywną i intersubiektywną pewność"'. Strauss twierdzi, że filozof - czyli ten, który rozpoznaje Prawdę o całości - potrzebuje przyjaciół i filozofów,

Ten akapit, opublikowany pierwotnie we francuskim wydaniu 0 tyranii w wydaniu amerykańskim pojawił się dopiero w roku $2000 \mathrm{i}$ to jako tłumaczony z francuskiego. Pozostaje tajemnicą, dlaczego Strauss go usunął.

Tamże, s. 168.

Tamże, s. 183. 
dusz dobrych i ułożonych, bo przebywanie wśród takich ludzi sprawia mu przyjemność i jest zdecydowanie bliższe wieczności, którą kontempluje, niż dusze złe i nieuporządkowane, których stara się unikać. Zaspokojenie filozofa nie jest więc tym samym co zaspokojenie - czyli szczęście - tyrana, skoro nie kierowałoby oboma pragnienie uznania. Filozof - ten który „próbuje przekroczyć człowieczeństwo" ${ }^{\text {"10 }}$ - osiąga samowystarczalność, jednak przelotne oglądanie wieczności za życia pozostawia w nim niedosyt. Stąd bierze się u niego poszukiwanie ludzi, których widziałby jako sobie podobnych. Władca, który również chce wychowywać swych poddanych, siłą rzeczy wychowuje wszystkich, filozof zaś, kierowany erosem ku dobru i dobrej naturze, zajmuje się tylko potencjalnymi filozofami, bądź dżentelmenami, życzliwymi mu, pragnącymi zapewnić warunki brzegowe jego życia (choćby w wymiarze „wiktu i opierunku”), uważając je za pożyteczne dla nich i dla miasta.

Jednak Strauss zgadza się z twierdzeniem Kojève'a, że to chrześcijaństwo stworzyło i urzeczywistniło ideę państwa uniwersalnego i homogenicznego. Jedyna możliwość buntu zawiera się w jego potencjalnej irracjonalności, stojącej a contra racjonalnego państwa ostatecznego. Bunt ten będzie jednak czystą negacją. Gdyby miał być czymś innym, wymagałby zapewne odniesienia - co sugeruje Strauss we wspomnianym ostatnim akapicie - do „wiecznego i niezmiennego porządku, w obrębie którego Historia zachodzi, a który nie jest nijak przez Historię dotknięty”"11. Innymi słowy, założenie Kojève’a, że człowiek jest obywatelem ziemi, że jest „absolutnie w domu” ${ }^{, 12}$, musiałoby być błędne.

Zbiór korespondencji, poza listami czysto prywatnymi, zawiera rozważania tego samego typu: po jednej stronie sytuujące perspektywę nieuchronnego końca historii, po drugiej - filozofii, która musiałaby transcendować, nie zaś tylko rozumieć i obejmować porządek historyczny, by być prawdziwa. W jednym z nich Strauss wprost powiela swoją tezę dotyczącą potencjalnie irracjonalnego buntu przeciwko homogenicznym instytucjom uniwersalnego państwa. Świadczy to tym dobitniej o wadze problemu i niezwykłej natarczywości myślenia we wzajemnych kontaktach obu myślicieli.

Nie istnieją idealne przekłady dzieł naprawdę głębokich i subtelnych. Tłumaczenie 0 tyranii może budzić pewne wątpliwości (aczkolwiek z pewnością nie większe, niż miałoby to miejsce w odniesieniu do innych

Tamże, s. 188.

Tamże, s. 200.

Tamże. 
publikacji Straussa w naszym kraju). Dialog Hieron został przedstawiony na podstawie (bardzo dobrej) wersji amerykańskiej, nie tłumaczono go więc z greki - wynikało to z ustaleń wydawcy. Greckie wyrazy, co także nie jest u nas normą, oddane zostały zgodnie z oryginałem. Książkę tę należy szczególnie polecać wszystkim tym, których interesuje niestandardowe ujęcie najważniejszych problemów ludzkości i nowoczesności. Pytania o człowieczeństwo, wieczność, filozofię w kontekście tyrańskiej obecności nowoczesnego, ostatniego, homogenicznego państwa z pewnością do nich należą. 